\title{
Comparison of p16ink4a immunostaining in benign and malignant HPV-related lesions
}

\author{
- Ana Paula Oliveira de Castro Department of Oral Pathology, School of Dentistry, University of São Paulo, São Paulo, SP, \\ Brazil - Priscila Lie Tobouti Department of Oral Pathology, School of Dentistry, University of São Paulo, São Paulo, SP, \\ Brazil • Suzana Cantanhede Orsini Machado de Sousa Department of Oral Pathology, School of Dentistry, University of São \\ Paulo, São Paulo, SP, Brazil
}

\begin{abstract}
Objective: To analyze the difference between p16inka immunostaining in normal epithelium, two benign HPV-related lesions (papilloma and condyloma acuminatum), and one malignant HPV-related lesion (oropharynx carcinoma). Methods: Five normal oral mucosas, fifteen papilloma, fifteen condyloma acuminatum, and fifteen HPV-positive oropharynx squamous cell carcinoma were included in this study. The histological sections were stained with anti-p16ink4a by immunohistochemistry. For the positive stain, the score was based on a scale of - to $3+$, as follows: - negative stain; $1+$ less than $25 \%$ of positivity and focal distribution; $2+26-50 \%$ of positivity and focal distribution; and $3+50-75 \%$ of positive cells and diffuse distribution. The evaluation of the intensity score was based on: - negative; 1- low intensity; 2- moderate intensity; 3- intensive. Results: The results showed no significant differences between the scores (positive $\mathrm{x}$ intensity) of p16ink4a in normal epithelium, papilloma, and condyloma acuminatum. All benign lesions and normal epithelium showed significant differences when compared with the oropharynx squamous cell carcinoma. Relevance: There are differences in the expression of p16ink4a between benign HPV-lesions and malignant HPV-lesions.
\end{abstract}

DESCRIPTORS | HPV; Papillomaviridae; p16; Condylomata Acuminata; Neoplasms of Squamous Cell.

RESUMO | Comparação da marcação de p16ink4a por imuno-histoquímica entre lesões benignas e malignas positivas para HPV • Objetivo: Analisar a diferença da marcação imuno-histoquímica de p16inka no epitélio normal, em duas lesões benignas associadas ao HPV (papiloma e condiloma acuminado) e uma lesão maligna relacionada ao HPV (carcinoma espinocelular de orofaringe). Material e métodos: Cinco mucosas normais, quinze papilomas, quinze condilomas acuminados e quinze carcinomas espinocelulares (CEC) positivos para HPV foram incluídos neste estudo. Os cortes histológicos foram corados com antip16ink4a por imuno-histoquímica. Para a marcação positiva, o escore foi baseado numa escala de - a 3+, sendo: - marcação negativa; $1+$ menos do que $25 \%$ de positividade e distribuição focal; 2+ 26-50\% de positividade e distribuição focal; 3+ 50-75\% de células positivas e distribuição difusa. A avaliação da pontuação da intensidade baseou-se em: - negativo; 1- baixa intensidade; 2- intensidade moderada; 3- intensiva. Resultados: Os resultados não mostraram diferenças significativas entre os escores (intensidade x positivo) de p16ink4a do epitélio normal, papiloma e condiloma acuminado. Todas as lesões benignas e o epitélio normal mostraram diferenças significativas quando comparadas com o CEC de orofaringe. Relevância: Há diferenças na expressão de p16ink4a entre lesões benignas e malignas positivas para HPV.

DESCRITORES | HPV; Papillomaviridae; p16; Condiloma Acuminado; Neoplasias de Células Escamosas.

CORRESPONDING AUTHOR | Priscila Lie Tobouti Department of Oral Pathology, School of Dentistry, University of São Paulo • Av. Prof. Lineu Prestes, 2227 São Paulo, SP, Brazil • 05508-900 E-mail: pritobouti@usp.br

- Received Apr 7, 2015 • Accepted May 4, 2015

- Dol http://dx.doi.org/10.11606/issn.2357-8041.clrd.2016.97169 


\section{INTRODUCTION}

Human papilloma virus (HPV) is a DNA virus of the Papillomaviridae family with approximately 7900 base pairs. There are over 150 different types divided into low-risk (e.g. HPV6 and HPV11) and high-risk (e.g. HPV16 and HPV18) HPV. Oral HPV transmission is not fully understood and assumptions include a subclinical infection, vertical transmission, and horizontal transmission. ${ }^{1}$ Horizontal transmission seems to be the most common route, including sexual transmission (orogenital contact). The self-inoculation virus from other skin sites or anogenital contact is also considered. ${ }^{2}$ The infection occurs in proliferating cells (basal cells) of a stratified squamous epithelium through microwounds. ${ }^{3}$ After the infection, the HPV genome can integrate in the nucleus as episome and replicate in synchrony with the host cellular DNA replication. ${ }^{4}$

The HPV genome has early genes, whose primary function is the episomal replication, and late genes, which encode the proteins of viral capsid. The early genes are divided into E1 to E7 and late ones into L1 / L2. The products of E1 and E2 genes are more specifically related to regulation of transcription and replication of the viral proteins. ${ }^{5,6}$

When there is integration of viral genome into the host cell genome, the genes may be altered or eliminated, leading to uncontrolled transcription of E6 and E7. ${ }^{1}$ Such oncoproteins are capable of interfering with important mechanisms controlling cell cycle and apoptosis and maintenance of chromosomal stability, deregulating the cell cycle control and inducing the cells into the $\mathrm{S}$ phase.3.7 It is believed that tumor cells result from the deregulation of two major cell cycle control pathways: the p53 pathway and pRB pathway. ${ }^{8}$

The cell cycle is controlled by cyclins, cyclin dependent kinases (CDKs), and their inhibitors. There are two main inhibitor groups: Cip / Kip (p21, p27, and p57) and INK / ARF (p16 and p14). ${ }^{9}$ These groups function as tumor suppressors and are often altered in tumors. These proteins bind to the complex cyclin / inactivate CDK and thus stop the cell cycle. p16ink4a is a protein encoded by the CDKN2A gene and acts as a tumor suppressor. P16 inhibits CDK4 (cyclin-dependentkinase 4), an important protein kinase during the $\mathrm{G} 1$ phase of the cell cycle. This kinase is responsible for the phosphorylation of retinoblastoma $(\mathrm{Rb})$ gene, a tumor suppressor. ${ }^{10}$ Mutations in CDK4 and changes of p16 and Rb may be present in carcinomas, particularly cancers associated with HPV. High-risk E7 binds to and inactivates $\mathrm{Rb}$, leading to an upregulation of p16. For this reason, the overexpression of this protein is target for identifying HPV positive cases. ${ }^{11}$ We aim to analyze the difference between p16inka immunostaining in normal epithelium, two benign HPV-related lesions (papilloma and condyloma acuminatum), and one malignant HPVrelated lesion (oropharynx carcinoma).

\section{MATERIAL AND METHODS}

\section{Tissue samples}

Ethics approval was obtained from the Human Research Ethics Committee (Protocol number: 10641412.2.0000.0075). Oral HPV-related diseases, diagnosed at the Oral Pathology Diagnostic Service of the School of Dentistry of University of São Paulo, were retrieved and fifteen papilloma, fifteen condyloma acuminatum, and fifteen HPVpositive oropharynx squamous cell carcinomas (OSCCs) were included in this study. Five normal oral mucosas were used as control. The HPVassociated OSCCs were chosen based in the intense positivity of p16ink4a, overexpression in more than $70 \%$ of the cells ${ }^{12}$ and with positive cytoplasm and nucleus. The OSCCs demonstrating weak or no positivity were excluded from this study. The histological sections were first stained with H\&E and reviewed by two observers. Then, the material was used for the IHQ. 


\section{Immunohistochemistry for p16ink4a}

Three-micrometer $(3 \mu \mathrm{m})$ serial sections from formalin-fixed paraffin-embedded blocks were obtained and mounted on poly-L-lysine-coated glass slides. Immunostaining was performed by the linked streptavidin-biotin horseradish peroxidase technique (LSAB-HRP) (Universal LSAB $\AA+$ Kit/ HRP, DAKO Carpinteria, CA, USA). The samples were deparaffinized in xylene followed by hydration in descending ethanol grades and then treated with $0.3 \% \mathrm{H}_{2} \mathrm{O}_{2}$ and $100 \%$ methanol for 15 minutes to quench endogenous peroxidase. Antigen retrieval was performed by heating specimens for 30 minutes at $95^{\circ} \mathrm{C}$ in sodium citrate. The sections were incubated overnight at $4^{\circ} \mathrm{C}$ with primary monoclonal anti-p16ink4a antibody (1:1000; Abcam 54210, clone2D9A12, Cambridge, MA, USA). After three washes with Tris buffer, the slides were treated with biotinylated species-specific secondary antibodies and streptavidin-biotin enzyme reagent (Universal LSAB $\AA+$ Kit/HRP, DAKO Carpinteria, CA, USA). The color was developed with 3,3'-diaminobenzidine tetrahydrochloride chromogen solution (Liquid Dab+ Substrate-Chromogen System, Dako, Carpinteria, CA, USA). Sections were counterstained with Mayer's haematoxylin (SigmaAldrich, St. Louis, MO, USA). Rat's liver was used as a positive control. The results were evaluated separately by three investigators.

\section{IImmunohistochemistry analysis}

For the evaluation of the p16INK4a immunostaining, a semi-quantitative analysis was performed using the scoring method for both intensity and positivity. Five randomly chosen areas were selected and analyzed in conventional light microscope (Olympus $\mathrm{CH} 2$ Olympus Optical Co. Ltd., Japan) with 400x magnification. An analysis of expression of p16INK4a was made based on the intensity distribution and on the proportion of cells positive for this marker.
Immunoreactivity was classified by a semi-quantitative score for both positivity and intensity of staining and the results were multiplied (positive $\mathrm{x}$ intensity). ${ }^{13}$ For the positive stain, the score was based on a scale of - to $3^{+}$, as follows: - negative stain; $1+$ less than $25 \%$ of positivity and focal distribution; $2+26-50 \%$ of positivity and focal distribution; and $3+51-75 \%$ of positive cells and diffuse distribution; $4+\geq 76 \%$ of positive and diffuse distribution. ${ }^{14}$ The evaluation of the intensity score was based on: - negative; 1- low intensity; 2- moderate intensity; 3- intensive. The nuclear and cytoplasm stain analysis were scored as positive or negative stain.

\section{Statistical analysis}

The data were analyzed using the GraphPad Prism 6.0 software (GraphPad Software Inc., San Diego, CA, USA). The results were analyzed first by the D'Agostino-Pearson omnibus test of normality. Results were not parametric, therefore we used Kruskal-Wallis test and Dunn's post-hoc test.

\section{RESULTS}

p16ink4a immunoscore was analyzed according to intensity, immunostain and distribution, and nuclear and cytoplasmic stain. The number of cases showing each score from samples of normal epithelium, papilloma, condyloma acuminatum, and oropharynx squamous cell carcinoma are shown in Table 1.

The reason for intensity and distribution analysis is that the positive staining of p16 is present and diffuse in all sections, but intensity was noticed to be different in each lesion group (Figure 1).

Despite papilloma showing a diffuse stain of p16ink4a, the intensity was low, especially when compared to squamous cell carcinoma of the oropharynx, which also shows scattered positive cells, but with a strong intensity (nucleus and cytoplasm) (Figure 1). 
Table 1 | P16ink4a expression patterns in normal mucosa, papilloma, condyloma acuminatum, and oropharynx squamous cell carcinoma.

\begin{tabular}{c|c|c|c|c|c|c|c|c|c|c|c|} 
& \multicolumn{3}{|c|}{ P16ink4a Intensity } & \multicolumn{9}{c|}{ P16ink4a Stain } & Nuclear Stain & Cytoplasmic Stain \\
\hline & 1 & 2 & 3 & 0 & +1 & +2 & +3 & +4 & + or - & + or - \\
\hline Normal (5) & 5 & 0 & 0 & 0 & 1 & 2 & 0 & 1 & + & - \\
\hline Papilloma (15) & 7 & 7 & 1 & 0 & 6 & 5 & 0 & 4 & + & - \\
\hline Condyloma(15) & 2 & 10 & 3 & 0 & 2 & 3 & 1 & 9 & + & - \\
\hline OPSCC (15) & 0 & 0 & 15 & 0 & 0 & 0 & 1 & 14 & + & + \\
\hline
\end{tabular}

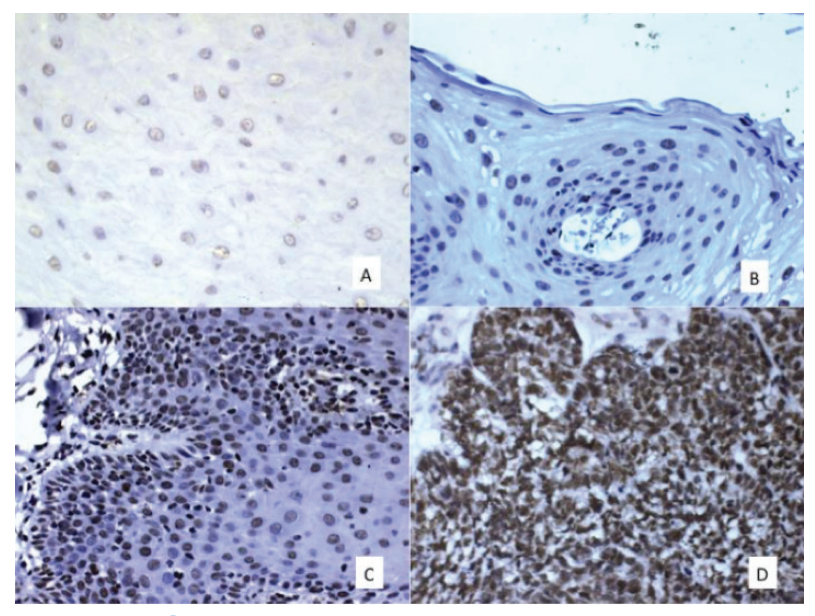

Figure 1 | p16ink4a immunohistochemistry stain. A. Normal epithelium; B. Papilloma; C. Condyloma; D. Oropharynx squamous cell carcinoma.

The results showed no significant differences between the scores (positive $\mathrm{x}$ intensity) of p16ink4a in normal epithelium (Figure 1A), papilloma (Figure 1B), and condyloma acuminatum (Figure $1 \mathrm{C}$ ). Hence, normal mucosa and benign lesions showed significant differences in p16ink4a staining when compared with the oropharynx squamous cell carcinoma (Figure 1D).

The differences of pr6ink4a immunostaining (intensity x distribution) between normal mucosa, benign, and malignant HPV-related lesions are shown in Figure 2.

\section{DISCUSSION}

The presence of HPV DNA in a tissue, by itself, does not mean that it will induce cancer. There are hundreds of different types of HPV, which are divided into low-risk and high-risk. Only the DNA of high-risk HPV, transcribed, which demonstrates to

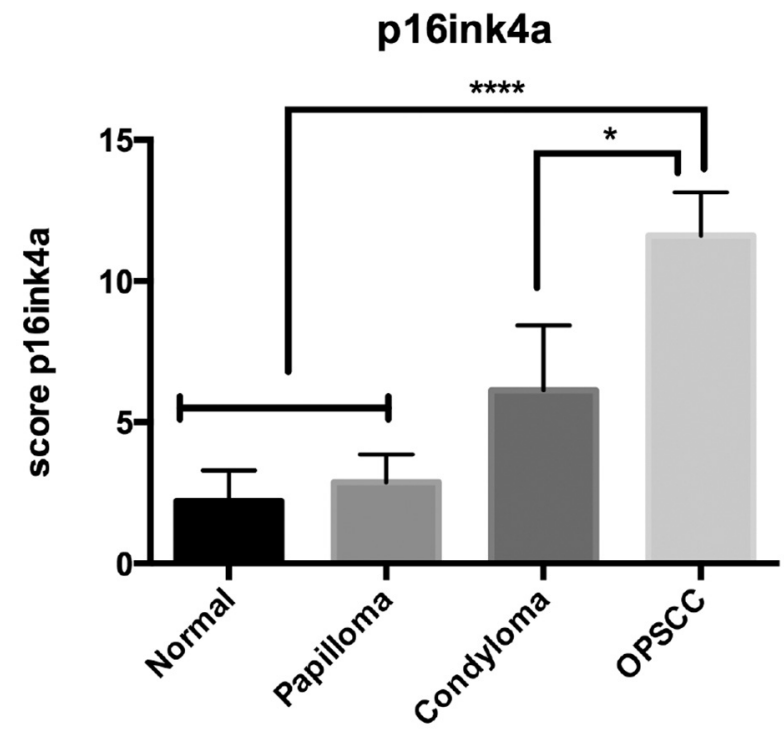

Figure 2 | Comparison of p16ink4a immunostaining between normal mucosa, benign, and malignant HPV-related lesions: OPSCC indicating significant differences when compared to normal mucosa, papilloma, and condyloma ( ${ }^{*} p<0.05 ; * * * * p<0.0001$ ).

be active, has clinical and biological relevance in the origin of HPV-OSCC. ${ }^{15}$ This is represented when HPV induces molecular changes resulting in malignant transformation.

p16-IHC has been used to detect high-risk HPV because of its sensitivity and because it does not only indicate the presence of HPV but also its activity, since the overexpression of p16 is caused by HPV oncoproteins. ${ }^{12,14}$ In situ hybridization technique is a less sensitive method than PCR for HPV DNA detection, but more specific than p16 immunostaining in the detection of HPV in carcinomas.7 But some authors believe that conventional HPV ISH nonspecific background is common and the test lacks sensitivity, ${ }^{14,16}$ as well as it 
is more expensive than IHC. Thus, the use of IHC is preferable. ${ }^{14}$

HPV interacts into the host genome and expresses the replication transcription factors E2, E6, and E7 oncoproteins, which repress transcription factors. ${ }^{3}$

Both low-risk and high-risk express E6 and E7, but, in the low-risk, E7 does not strongly affect the centrosome homeostasis. Still in the high-risk, E6 and E7 squeal the cell centrosome and cause mitotic abnormalities. ${ }^{17}$ Also, in low-risk HPV, E6 and E7 do not immortalize keratinocytes in vitro, as they do in high-risk..$^{18}$ Other studies show differences between low and high-risk E6 and E7 and demonstrate that even though both, low and highrisk oncoproteins, are capable of binding to p53 C-terminus, only high-risk E6 oncoproteins are capable of destroying $\mathrm{p} 53 \cdot{ }^{19}$

High-risk E6 binds to and inactivates p53, leading to its degradation. The degradation of this important tumor suppressor alters the cell cycle, leading to a malignant transformation. Also, highrisk E7 binds to another tumor suppressor, retinoblastoma ( $\mathrm{Rb})$. Once it binds to $\mathrm{Rb}$, it releases the E2F transcription factor, leading it from $\mathrm{G} 1$ to $\mathrm{S}$ cell cycle phases. Low levels of $\mathrm{Rb}$ lead to overexpression of p16. Therefore, the finding of overexpression of p16 has been associated with the presence of HPV in its active form. The use of this marker is very helpful, especially because carcinomas of head and neck related to tobacco showed loss of p16 expression. ${ }^{20-23}$ However, low-risk E7 binds to $\mathrm{Rb}$ but fails to degrade it. Giarrè et al. ${ }^{24}$ showed that HPV16 E7 subverts G1-S capture and that HPV1 E7 is less efficient in overcoming G1 cell cycle, ${ }^{24}$ consequently it should not overexpress p16, as showed in this study.

Thus, normal epithelium, negative for HPV, and oral benign low-risk HPV lesions such as papilloma and condyloma, were expected not to show strong expression of p16ink4a, as seen in our results. It is known that condyloma acuminatum may present low-risk and high-risk HPV, ${ }^{25,26}$ and possibly may release proteins that increase p16 expression, as seen in our cases, which showed a strong positive nucleus but not cytoplasmatic expression. According to this study, there were no significant differences between the two benign lesions used and normal epithelium, even if some samples showed nuclear staining for p16. Thus, the presence of HPV cannot be assured only by the positivity to p16ink4a-IHC in those cases.

The correlation of p16 with high-risk HPV has caused great debates, since different studies used different IHC methods and antibodies, and they could cause false-positive or false-negative results. But, based in a systematic review, ${ }^{12}$ we considered the correlation between p16-IHC and HPV in cases showing 16 overexpression in more than $70 \%$ of the cells and with cytoplasm and nucleus with positive stain. Thus, our results showed a significant difference between HPV-OSCC and HPV-benign lesions, as well as normal epithelium. OPSCC was the only group that showed both cytoplasmatic and nuclear stain. The other groups showed only nuclear stain.

In conclusion, we observed differences in the expression of p16ink4a between benign HPVlesions and malignant HPV-lesions.

\section{ACKNOWLEDGEMENTS}

The authors would like to thank Fundação de Amparo à Pesquisa do Estado de São Paulo (FAPESP), process number 2012/21684-2 and 2013/05430-3, for the financial support.

\section{REFERENCES}

1. Pinheiro RS, de França TR, Rocha B, Ferreira DC, Ribeiro CM, Cavalcanti SM, et al. Human papillomavirus coinfection in the oral cavity of HIV-infected children. J Clin Pathol. 2011 Dec;64(12):1083-7. doi: 10.1136/jclinpath-2011-200187. 
2. Kumaraswamy KL, Vidhya M. Human papilloma virus and oral infections: an update. J Cancer Res Ther. 2011 AprJun;7(2):120-7. doi: 10.4103/0973-1482.82915.

3. Moody CA, Laimins LA. Human papillomavirus oncoproteins: pathways to transformation. Nat Rev Cancer. 2010 Aug;10(8):550-6o. doi: 10.1038/nrc2886.

4. Ziegert C, Wentzensen N, Vinokurova S, Kisseljov F, Einenkel $\mathrm{J}$, Hoeckel M, et al. A comprehensive analysis of HPV integration loci in anogenital lesions combining transcript and genome-based amplification techniques. Oncogene. 2003 Jun 19;22(25):3977-84. doi:10.1038/sj.onc.12066295.

5. Schuck S, Ruse C, Stenlund A. CK2 phosphorylation inactivates DNA binding by the papillomavirus E1 and E2 proteins. J Virol. 2013 Jul;87(13):7668-79. doi: 10.1128/JVI.00345-13.

6. Võsa L, Sudakov A, Remm M, Ustav M, Kurg R. Identification and analysis of papillomavirus E2 protein binding sites in the human genome. J Virol. 2012 Jan;86(1):348-57. doi: 10.1128/JVI.05606-11.

7. Wentzensen N, Vinokurova S, von Knebel Doeberitz M. Systematic review of genomic integration sites of human papillomavirus genomes in epithelial dysplasia and invasive cancer of the female lower genital tract. Cancer Res. 2004 Jun 1;64(11):3878-84. doi: 10.1158/ooo8-5472.CAN-04-00o9.

8. Fregonesi PA, Teresa DB, Duarte RA, Neto CB, de Oliveira MR, Soares CP. p16(INK4A) immunohistochemical overexpression in premalignant and malignant oral lesions infected with human papillomavirus. J Histochem Cytochem. 2003 Oct;51(10):1291-7.

9. Cerqueira A, Martín A, Symonds CE, Odajima J, Dubus P, Barbacid M, et al. Genetic characterization of the role of the Cip/Kip family of proteins as cyclin-dependent kinase inhibitors and assembly factors. Mol Cell Biol. 2014 Apr;34(8):1452-9. doi: 10.1128/MCB.01163-13.

10. Cardesa A, Nadal A. Carcinoma of the head and neck in the HPV era. Acta Dermatovenerol Alp Pannonica Adriat. 2011 Sep;20(3):161-73.

11. Ha PK, Califano JA. The role of human papillomavirus in oral carcinogenesis. Crit Rev Oral Biol Med. 2004 Jul 1;15(4):18896. doi: 10.1177/154411130401500402 .

12. Grønhøj Larsen C, Gyldenløve M, Jensen DH, Therkildsen MH, Kiss K, Norrild B, et al. Correlation between human papillomavirus and p16 overexpression in oropharyngeal tumours: a systematic review. Br J Cancer. 2014 Mar 18;110(6):1587-94. doi: 10.1038/bjc.2014.42.

13. Charafe-Jauffret E, Tarpin C, Bardou VJ, Bertucci F, Ginestier $\mathrm{C}$, Braud AC, et al. Immunophenotypic analysis of inflammato- ry breast cancers: identification of an 'inflammatory signature'. J Pathol. 2004 Mar;202(3):265-73. doi: 10.1002/path.1515.

14. Lewis JS Jr., Thorstad WL, Chernock RD, Haughey BH, Yip $\mathrm{JH}$, Zhang Q, et al. p16 positive oropharyngeal squamous cell carcinoma: an entity with a favorable prognosis regardless of tumor HPV status. Am J Surg Pathol. 2010 Aug;34(8):108896. doi: 10.1097/PAS.obo13e3181e84652.

15. Curado MP, Boyle P. Epidemiology of head and neck squamous cell carcinoma not related to tobacco or alcohol. Curr Opin Oncol. 2013 May;25(3):229-34. doi: 10.1097/ CCO.obo13e32835ff $48 \mathrm{c}$.

16. Guo M, Gong Y, Deavers M, Silva EG, Jan YJ, Cogdell DE, et al. Evaluation of a commercialized in situ hybridization assay for detecting human papillomavirus DNA in tissue specimens from patients with cervical intraepithelial neoplasia and cervical carcinoma. J Clin Microbiol. 2008 Jan;46(1):274-80. doi: 10.1128/JCM.01299-07.

17. Duensing S, Duensing A, Flores ER, Do A, Lambert PF, Münger K. Centrosome abnormalities and genomic instability by episomal expression of human papillomavirus type 16 in raft cultures of human keratinocytes. J Virol. 2001 Aug;75(16):7712-6. doi: 10.1128/JVI.75.16.7712-7716.2001.

18. Thomas JT, Oh ST, Terhune SS, Laimins LA. Cellular changes induced by low-risk human papillomavirus type 11 in keratinocytes that stably maintain viral episomes. J Virol. 2001 Aug;75(16):7564-71. doi: 10.1128/JVI.75.16.7564-7571.2001.

19. Mantovani F, Banks L. The human papillomavirus E6 protein and its contribution to malignant progression. Oncogene. 2001 Nov 26;20(54):7874-87.

20. O’Rorke MA, Ellison MV, Murray LJ, Moran M, James J, Anderson LA. Human papillomavirus related head and neck cancer survival: a systematic review and meta-analysis. Oral Oncol. 2012 Dec;48(12):1191-201. doi: 10.1016/j.oraloncology.2012.06.019.

21. Santarelli A, Lo Russo L, Bambini F, Campisi G, Lo Muzio L. New perspectives in medical approach to therapy of head and neck squamous cell carcinoma. Minerva Stomatol. 2009 Sept;58(9):445-52.

22. Weinberger PM, Yu Z, Haffty BG, Kowalski D, Harigopal M, Brandsma J, et al. Molecular classification identifies a subset of human papillomavirus-associated oropharyngeal cancers with favorable prognosis. J Clin Oncol. 2006 Feb 10;24(5):736-47. doi: 10.1200/JCO.2004.00.3335 -

23. Psyrri A, Gouveris P, Vermorken JB. Human papillomavirusrelated head and neck tumors: clinical and research implication. Curr Opin Oncol. 2009 May;21(3):201-5. doi: 10.1097/ CCO.obo13e328329ab64. 
24. Giarrè M, Caldeira S, Malanchi I, Ciccolini F, Leão MJ, Tommasino M. Induction of $\mathrm{pRb}$ degradation by the human papillomavirus type $16 \mathrm{E} 7$ protein is essential to efficiently overcome p16INK4a-imposed G1 cell cycle Arrest. J Virol. 2001 May;75(10):4705-12. doi: 10.1128/JVI.75.10.47054712.2001.
25. Kui LL, Xiu HZ, Ning LY. Condyloma acuminatum and human papilloma virus infection in the oral mucosa of children. Pediatr Dent. 2003 Mar-Apr;25(2):149-53.

26. Neville BWD, Damm DD, Allen CM, Bouquot JE. Oral and maxillofacial pathology. 3rd ed. St. Louis, Mo: Saunders/ Elsevier, 2008. 